\title{
Australian Journal of

\section{Growth regulators and carving on breakage of apical dominance in tannia [Xanthosoma sagittifolium (L.) Schott] rhizomes}

\author{
Cristina Soares de Souza*, Ana Paula Sato Ferreira, Fernando Luiz Finger \\ Department of Plant Science, Federal University of Viçosa (UFV) 36570-000, Viçosa, MG, Brazil
}

\author{
*Corresponding author: cristina.genetica@gmail.com
}

\begin{abstract}
Specific clones of tannia are commonly used as cooking leaves in some Brazilian states. The crop is propagated exclusively as exually by planting the rhizomes usually after a few years of production. Because of that, there is the need to establish strategies to propagate healthy plantlets with higher sprouting rate for leaf production. This work had the goals to evaluate the influence of growth regulators and carving of the rhizomes sprouting and growth of tannia. Cured rhizomes from the clone 'Caipira' were stored for three months at $5^{\circ} \mathrm{C}$ and $89 \%$ relative humidity. Afterward, the top of half of the rhizomes were carved in a V shape at the top (carving), to stimulate lateral sprouting. The rhizomes were submerged for 30 minutes in solutions containing 6-benzylaminopurine (BAP) and/or 2chloroethylphosphonic acid (ethephon), and the respective control. The production of new leaves and expansion of leaf area were stimulated by treating the rhizomes with $500 \mathrm{mg} \mathrm{L}^{-1} \mathrm{BAP}$ and $250 \mathrm{mg} \mathrm{L}^{-1} \mathrm{BAP}+250 \mathrm{mg} \mathrm{L}^{-1}$ ethephon. Regardless the use of growth regulators, the carving induced higher number of new sprouted leaves after 35 days of planting. Similarly, rhizomes treated with 500 $\mathrm{mg} \mathrm{L}^{-1} \mathrm{BAP}$ or $250 \mathrm{mg} \mathrm{L}^{-1} \mathrm{BAP}+250 \mathrm{mg} \mathrm{L}^{-1}$ ethephon had higher number of sprouts after 49 days of planting. Sprouting was anticipated when the carved rhizomes were treated with $250 \mathrm{mg} \mathrm{L}^{-1} \mathrm{BAP}+250 \mathrm{mg} \mathrm{L}^{-1}$ ethephon.
\end{abstract}

Keywords: Xanthosoma sagittifolium, Carving, Ethephon, 6-benzylaminopurine, Sprouting.

Abbreviations: ANOVA_analysis of variance, BAP_ 6-benzylaminopurine, Ethephon 2-chloroethylphosphonic acid, N:P:K_ nitrogen:phosphorus:potassium.

\section{Introduction}

The species Xanthosoma sagittifolium (L.) Schott, is a popular leaf vegetable consumed by many Brazilians. The rhizomes also can be used as source of starch (Rubatzky and Yamaguchi, 1997). The plant belonging to the family araceae is known by the name of 'taioba' being cultivated in tropical and subtropical climate regions of Brazil (Souza et al., 2014). The propagation of tannia is vegetative by using small rhizomes, planted after the cold season is over (Carvalho and Cordeiro, 1990; Filgueira, 2008). But, little is known about the physiology and effect of handling in the rate of sprouting. The lack of propagation organs is a major problem that has hindered the deployment of vegetative propagated crops (Carvalho, 1991; Fogaça et al., 2007). Alternative methods of rapid propagation can solve the problem of this shortage and reduce the time and cost of production. Cytokinins are growth regulators that are active during the process of cell division, mobilization of nutrients, apical dominance and dormancy breakage (Coleman et al., 2001; Garcia et al., 2006; García-Flórez et al., 2009). Among these, control of cell division is of considerable significance in the growth and development of the plant. Cytokinins have an active function on the growth of lateral buds, reducing the apical dominance, and increasing the rate of sprouting (Erig and Schuch, 2006; Vieira et al., 2009). According to GarcíaFlórez et al. (2009) the development of lateral buds are inhibited by the increased concentration of IAA (3-indolylacetic acid) on the apical meristem, to act as a drain of nutrients and cytokinins for the apical bud. Moreover, the high level of auxin in the apical buds aids in maintaining high levels of ABA (abscisic acid) in lateral buds, inhibiting their growth (Taiz and Zeiger, 2002). Thus, removal of the apical bud promote the increase of cytokinins in lateral buds, favoring the development of these. Among the most commonly used cytokinins is 6-benzylaminopurine (BAP) (García-Flórez et al., 2009). The role of 6-benzylaminopurine on the sprouting of tannia rhizomes is not known yet. In addition to that, there is no information available on if by removing the apical dominant bud promotes an increase in the cytokinins in the lateral buds, thereby stimulating their growth. The stimulation of cell division can also be caused by the application of ethylene, resulting in the formation of shoots and adventitious roots (Oliveira et al., 2001). Ethylene is one of the growth regulators commonly used in agriculture, due to the effects of many physiological processes. Due to the high diffusion rate (gas hormone), it becomes difficult to apply in plants, under field conditions (Suttle, 2009). However, this limitation can be overcome by the use of compounds that release ethylene (Coleman et al., 2001). The most widely used is ethephon (2-chloroethylphosphonic acid), commercially known as Ethrel. It is also possible that the exogenous ethylene to stimulate increased synthesis of giberellins (growth promoter hormone), and may thus increase or decrease the sprouting tubers, depending on the concentration and duration of exposure (Suttle, 1998). In a 
previous study on yam tuber of Dioscorea cayennensis the use of acetylene induced sprouting and formation of adventitious roots on the sprouting tubers (Oliveira et al., 2001). Thus, ethylene seems to be directly involved in the induction of sprouting and root differentiation. Nevertheless, the influence of ethylene on the sprouting of tannia rhizomes has not yet been determined. The goal of this work was to determine the effect of 6-benzylaminopurine (BAP) and 2chloroethylphosphonic acid (ethephon), combined with the carving of the apical bud on the sprouting of tannia rhizomes.

\section{Results}

\section{Growth regulators}

Regardless of, if the rhizomes were or were not carved, the growth regulators BAP and ethephon improved most of the measured plant growth characteristics. Applying $500 \mathrm{mg} \mathrm{L}^{-1}$ BAP or $250 \mathrm{mg} \mathrm{L}^{-1} \mathrm{BAP}+250 \mathrm{mg} \mathrm{L}^{-1}$ ethephon enhanced the production of leaves compared to control, increasing the number of leaves by $97 \%$ and $65.45 \%$, respectively (Table 1 ). All the other combinations of BAP or ethephon had a similar effect of the number of leaves. Only the $500 \mathrm{mg} \mathrm{L}^{-1} \mathrm{BAP}+$ $500 \mathrm{mg} \mathrm{L}^{-1}$ ethephon, had an effect on the total leaf area. The treatment of $500 \mathrm{mg} \mathrm{L}^{-1} \mathrm{BAP}+500 \mathrm{mg} \mathrm{L}^{-1}$ ethephon shortened the height of the plants compared to other plants treated with growth regulators (Table 1). Smaller fresh leaf matter production occurred when the rhizomes were treated with $500 \mathrm{mg} \mathrm{L}^{-1} \mathrm{BAP}+500 \mathrm{mg} \mathrm{L}^{-1}$ ethephon, but did not affect the total dry production of leaves.

\section{Carving}

Carving the apical bud did not affect the total production of leaves per rhizome (Table 2). But, the addition of BAP and/or ethephon helped the growth of lateral buds (Table 3). The excision of the main bud reduced the final leaf area, length of the aerial part, total fresh and dry matter (Table 2). When the rhizomes were carved, a more uniform sprouting was obtained, which increased the number of sprouting leaves by $16 \%$ after 35 days from planting (data not shown). This result showed that the stimulus of lateral buds sprouting was affected by the presence of the main bud. Nevertheless, the total production of fresh and dry matter of leaves at 120 days was lower in the carved rhizomes (Table 2).Irrespective of if the rhizomes were or were not carved, the treatment with 500 $\mathrm{mg} \mathrm{L}^{-1} \mathrm{BAP}$ or $250 \mathrm{mg} \mathrm{L}^{-1} \mathrm{BAP}+250 \mathrm{mg} \mathrm{L}^{-1}$ ethephon resulted in the higher number of new sprouting leaves after 49 days of planting (Table 3). These results show that uniform sprouting requires growth regulator, with the control rhizomes having the lowest sprouting among the treatments (Table 3). Carving was able to improve the final number of sprouted leaves after 120 days after planting (Fig 2).

\section{Discussion}

The highest number of shoots from rhizomes submitted to removal of the apical meristem (carved) due to the strong control that this has on the lateral buds. The carving caused rapid resumption of cell division and the development of lateral meristems. Such control is exercised through some auxin, possibly the 3-indolyl-acetic acid (IAA), synthesized in the apical region and transported to the lateral meristem. Thus, the removal of the apical meristem afforded the increased availability of cytokinins in the lateral meristems (García-Flórez et al., 2009). Cytokinins are also crucial in promoting budding gems in propagative organs (GarcíaFlórez et al., 2009). 6- benzylaminopurine acted on the control of the hydrolysis of the rhizomes reserves being necessary for induction of $\alpha$-amylase to hydrolyze starch. According to Vieira et al. (2008) the development of amylase activity is an important event and can be detected during early germination, and its main function available substrates used for seedling until it becomes photosynthetically selfsufficient. These nutritional reserves, digested by the enzyme accumulated in the form of sugars, amino acids and nucleic acids are then transported to the lateral buds in the rhizomes. According to Ono et al. (2004), breaking the apical dominance can be promoted with synthetic cytokinins, but working with papaya (Carica papaya L.) found that cytokinin used isolated, with and without the removal of the apical meristem, does not increase the growth of side shoots. Coelho et al. (2009) studied the growth regulators effect on the propagation of pineapple 'Smooth Cayenne', found higher efficiency of treatment with 6-benzylaminopurine in a concentration of $400 \mathrm{mg} \mathrm{L}^{-1}$ on the shoot buds. Souza and Finger (2014) reported that pre-treatment of the rhizomes with growth regulators BAP $\left(250 \mathrm{mg} \mathrm{L}^{-1}\right)+$ Ethrel $(250 \mathrm{mg}$ $\mathrm{L}^{-1}$ ) does not induce greater formation of lateral buds in tannia genotypes Comum, Roxa and Caxixe. The promoting effect of ethylene (Ethrel) is to increase the release and the movement of these hydrolytic enzymes and cause increased breathing and sugar content (Suttle, 2009).

\section{Materials and Methods}

\section{Preparation and storage of rhizomes}

Rhizomes from tannia (Xanthosoma sagittifolium) from clone 'Caipira', with medium size (approximately 25g), were harvested at Inhapim, MG, Brazil and transported to the Universidade Federal de Viçosa (UFV), Viçosa, MG. The rhizomes were allowed to cure for 20 days at room temperature in a shaded greenhouse and then, stored in cast boxes of polypropylene, with lid, for three months, at $5^{\circ} \mathrm{C}$ and $89 \%$ relative humidity.

\section{Treatments and experimental design}

The experiment was conducted in a factorial $7 \times 2$, being composed by combining six concentrations of plant growth regulators, more control with water in rhizomes carved and uncarved in completely randomized design with 6 repetitions. Each experimental unit was composed by one plant. After three months the rhizomes were removed from the cold storage, in half of the rhizomes the apical bud was removed by carving in a "V" shape form (Fig 1). Afterwards, the carved and uncarved rhizomes were dipped for 30 minutes in solutions containing: (1) water (control treatment); (2) 250 $\mathrm{mg} \mathrm{L}^{-1} \mathrm{BAP}$; (3) $500 \mathrm{mg} \mathrm{L}^{-1} \mathrm{BAP}$; (4) $250 \mathrm{mg} \mathrm{L}^{-1}$ ethephon; (5) $500 \mathrm{mg} \mathrm{L}^{-1}$ ethephon; (6) $250 \mathrm{mg} \mathrm{L}^{-1} \mathrm{BAP}+250 \mathrm{mg} \mathrm{L}^{-1}$ ethephon; (7) $500 \mathrm{mg} \mathrm{L}^{-1} \mathrm{BAP}+500 \mathrm{mg} \mathrm{L}^{-1}$ ethephon. The rhizomes were allowed to dry for three days over a bench at room temperature and subsequently planted into one liter pots. After three months the plantlets were transplanted to five liter pots filled with $75 \%$ soil, $25 \%$ organic matter and $30 \mathrm{~g}$ of commercial fertilizer N:P:K (4:14:8).

\section{Traits measured}

The number of sprouting leaves was determined weekly and at 120 days after planting the number of leaves, length of aerial portion of the plant, leaf area, fresh and dry matter were also determined. The variable number of shoots, evaluations were made periodically every 7 days, from the time the rhizomes began to sprout. The shoot length was 
Table 1. Average number of leaves (NL), leaf area $\left(\mathrm{cm}^{2}\right)(\mathrm{LA})$, length of aerial portion of the plant $(\mathrm{cm})(\mathrm{LL})$, fresh matter $(\mathrm{g})(\mathrm{FM})$ and dry matter (g) (DM) of tannia 'Caipira', carved or uncarved, after 3 months storage at $5^{\circ} \mathrm{C}$ following application of different concentrations of growth regulators.

\begin{tabular}{|c|c|c|c|c|c|c|c|c|c|c|}
\hline \multirow{2}{*}{ Treatments } & \multicolumn{10}{|c|}{ Means } \\
\hline & $\mathrm{NL}$ & & LA & & LL & & FM & & DM & \\
\hline Control & 6.5 & $\mathrm{~b}$ & 435 & $\mathrm{a}$ & 48.7 & $\mathrm{ab}$ & 156.3 & $\mathrm{ab}$ & 9.4 & $\mathrm{a}$ \\
\hline $250 \mathrm{mg} \mathrm{L}^{-1}$ ethephon & 9.8 & $\mathrm{ab}$ & 419 & $\mathrm{ab}$ & 53.1 & a & 206.3 & $\mathrm{ab}$ & 11.4 & $\mathrm{a}$ \\
\hline $500 \mathrm{mg} \mathrm{L}^{-1}$ ethephon & 9.0 & ab & 440 & a & 53.5 & a & 203.5 & $\mathrm{ab}$ & 11.0 & $\mathrm{a}$ \\
\hline $250 \mathrm{mg} \mathrm{L}^{-1} \mathrm{BAP}$ & 8.7 & $a b$ & 425 & $\mathrm{ab}$ & 50.8 & a & 187.1 & $\mathrm{ab}$ & 11.5 & $\mathrm{a}$ \\
\hline $500 \mathrm{mg} \mathrm{L}^{-1} \mathrm{BAP}$ & 12.0 & $\mathrm{a}$ & 433 & $\mathrm{ab}$ & 55.5 & a & 207.2 & $\mathrm{ab}$ & 12.6 & $a$ \\
\hline $250 \mathrm{mg} \mathrm{L}^{-1} \mathrm{BAP}+250 \mathrm{mg} \mathrm{L}^{-1}$ ethephon & 10.7 & a & 438 & a & 53.5 & a & 221.8 & a & 12.6 & a \\
\hline $500 \mathrm{mg} \mathrm{L}^{-1} \mathrm{BAP}+500 \mathrm{mg} \mathrm{L}^{-1}$ ethephon & 9.2 & $\mathrm{ab}$ & 397 & $\mathrm{~b}$ & 40.2 & $\mathrm{~b}$ & 136.7 & $\mathrm{~b}$ & 8.8 & a \\
\hline
\end{tabular}

Mean followed by the same letter do not differ by Tukey test at $\mathrm{P} \leq 0.05$.

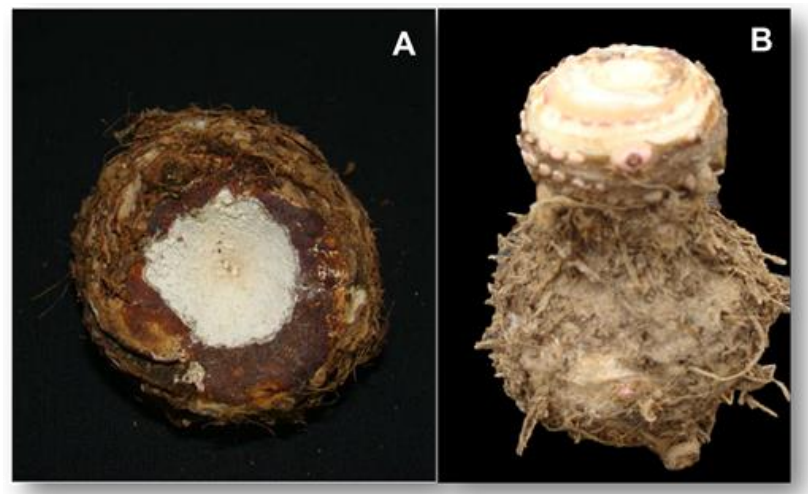

Fig 1. Rhizomes of tannia genotype 'Caipira' without apical meristem (carved) (A) and with apical meristem (uncarved) (B).

Table 2. Average number of leaves (NL), leaf area $\left(\mathrm{cm}^{2}\right)(\mathrm{LA})$, length of aerial portion of the plant $(\mathrm{cm})(\mathrm{LL})$, fresh matter $(\mathrm{g})(\mathrm{FM})$ and dry matter $(\mathrm{g})(\mathrm{DM})$ of tannia 'Caipira', carved or uncarved, after 3 months storage at $5^{\circ} \mathrm{C}$ following application of different concentrations of growth regulators.

\begin{tabular}{|c|c|c|c|c|c|c|c|c|c|c|}
\hline \multirow[b]{2}{*}{ Carving } & \multicolumn{10}{|c|}{ Means } \\
\hline & NL & & LA & & LL & & FM & & $\mathrm{DM}$ & \\
\hline Carved & 10.1 & a & 413 & b & 47.9 & b & 175.3 & b & 10.0 & b \\
\hline Uncarved & 8.7 & a & 440 & a & 53.6 & a & 201.5 & a & 12.1 & a \\
\hline
\end{tabular}

Mean followed by the same letter do not differ by Tukey test at $\mathrm{P} \leq 0.05$.

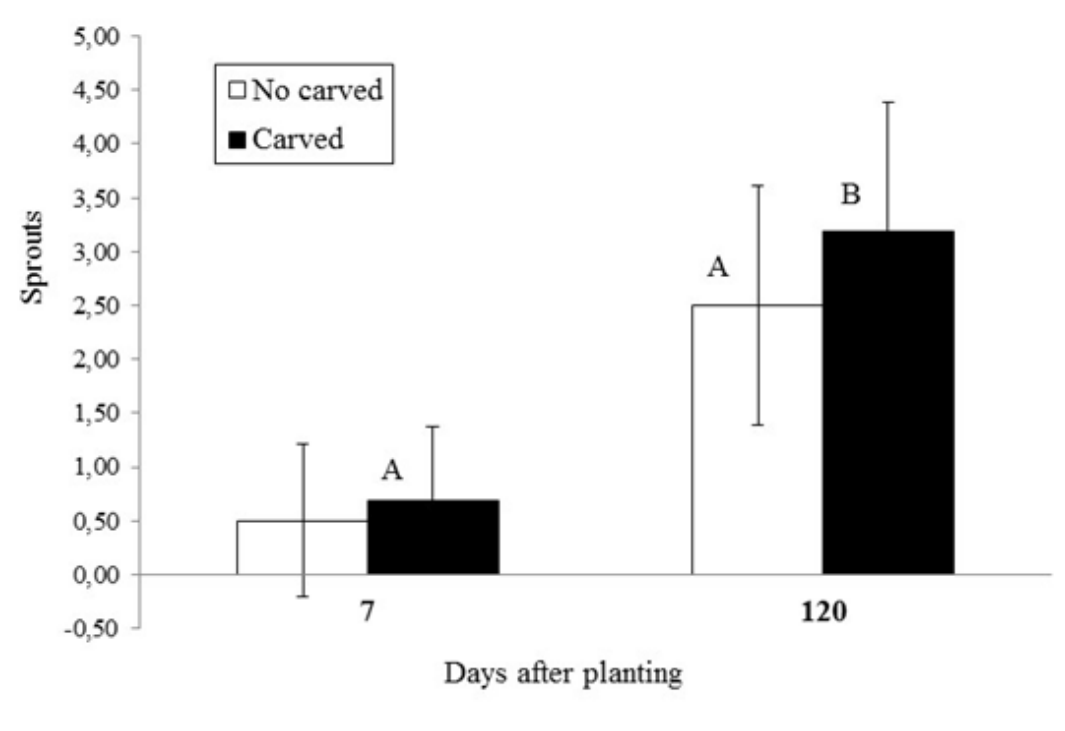

Fig 2. Number of sprouts of tannia 'Caipira' with apical meristem (uncarved) or without apical meristem (carved), after 3 months storage at $5^{\circ} \mathrm{C}$. Mean followed by the same letter do not differ by Tukey test at $\mathrm{P} \leq 0.05$. 
Table 3. Mean values of sprouting leaves (SL) of tannia 'Caipira', carved or uncarved, after 3 months storage at $5^{\circ} \mathrm{C}$ and application of different concentrations of growth regulators.

\begin{tabular}{ll}
\hline Treatment & SL \\
\hline Control & $1.6^{\mathrm{g}}$ \\
$250 \mathrm{mg} \mathrm{L}^{-1}$ ethephon & $2.3^{\mathrm{c}}$ \\
$500 \mathrm{mg} \mathrm{L}^{-1}$ ethephon & $1.9^{\mathrm{e}}$ \\
$250 \mathrm{mg} \mathrm{L}^{-1} \mathrm{BAP}$ & $1.8^{\mathrm{f}}$ \\
$500 \mathrm{mg} \mathrm{L}^{-1} \mathrm{BAP}$ & $2.3^{\mathrm{b}}$ \\
$250 \mathrm{mg} \mathrm{L}^{-1} \mathrm{BAP}+250 \mathrm{mg} \mathrm{L}^{-1}$ ethephon & $2.4^{\mathrm{a}}$ \\
$500 \mathrm{mg} \mathrm{L}^{-1} \mathrm{BAP}+500 \mathrm{mg} \mathrm{L}^{-1}$ ethephon & $2.0^{\mathrm{d}}$ \\
\hline
\end{tabular}

measured by the distance of the cutting point, just above the base of the petiole to the apex of the leaf blade. The leaf area was determined by measuring the length and width, wherein the length was obtained for the distance between the apex and leaf lamina and the insertion point of the petiole and the width was taken as the sum of the distances between the insertion of petiole and the ends of the two major side ribs (Chapman, 1964). The fresh weight of the aerial part was obtained by weighing on an analytical balance, accurate to three decimal places. The dry matter was determined by drying the plants in an oven with forced ventilation at $70^{\circ} \mathrm{C}$ for 72 hours, where it obtained a constant weight (Seganfredo et al., 2001).

\section{Statistical analysis}

Data were submitted to analysis of variance ANOVA and the means were compared by Tukey at $\mathrm{P} \leq 0.05$, using the statistical program SAEG version 9.1 (2007).

\section{Conclusions}

The production of new leaves and leaf area expansion are stimulated by treatment of tannia rhizomes with $500 \mathrm{mg} \mathrm{L}^{-}$ ${ }^{1} \mathrm{BAP}$ and $250 \mathrm{mg} \mathrm{L}^{-1} \mathrm{BAP}+250 \mathrm{mg} \mathrm{L}^{-1}$ of ethephon. Carving induces more new sprouting leaves, as determined at 35 days after planting. The treatment with $250 \mathrm{mg} \mathrm{L}^{-1} \mathrm{BAP}+$ $250 \mathrm{mg} \mathrm{L}^{-1}$ of ethephon in carved rhizomes, provides optimal sprouting of lateral buds in this cultivar.

\section{Acknowledgements}

The authors thank Fundação de Amparo a Pesquisa de Minas Gerais (FAPEMIG) and Conselho Nacional de Desenvolvimento Científico e Tecnológico (CNPq) for the financial support and scholarships.

\section{References}

Carvalho EF, Cordeiro JAD (1990) Um método alternativo e eficiente de propagação vegetativa de inhame (Colocasia esculenta (L.) Schott) e de taioba (Xanthosoma sagittifolium (L.) Schott). Acta Amaz. 20:11-18.

Carvalho EF (1991) Propagação de inhame (Colocasia esculenta (L.) Schott) pelo método de divisão de rizomas. Rev Ciênc Agron. 22:61-66.

Chapman T (1964) A note on the measurement of leaf area of the tannia (Xanthosoma sagittifolium). Trop Agric. 41:351-352.

Coelho RI, Carvalho AJC, Thiebaut JTL, Lopes JC (2009) Brotações de gemas em secções de caule de abacaxizeiro 'Smooth Cayenne' tratadas com reguladores de crescimento. Rev Bras Frutic. 31:203-209.

Coleman WK, Donnelly DJ, Coleman SE (2001) Potato microtubers as research tools: a review. Am J Potato Res. 78:47-55.
Erig AC, Schuch MW (2006) Ação da 6-benzilaminopurina e da qualidade da luz na multiplicação in vitro de macieira (Malus domestica Borkh.) cvs. Galaxy e Mastergala. Rev Bras Agrocienc. 12:151-155.

Filgueira FAR (2008) Novo manual de olericultura: agrotecnologia moderna na produção e comercialização de hortaliças, $3^{\mathrm{a}}$ ed. Viçosa: UFV. 421p.

Fogaça CM, Cordeiro DC, Correia TD, Lauriano MP, Sant'annaSantos BF, Finger FL, Otoni WC (2007) Microtuberização de Colocasia esculenta L. Schott (Aracea) in vitro. Rev Bras Biociênc. 5:123-125.

Garcia AS, Branquinho EGA, Menuchi ACTP, Erlacher KC, Domingues MCS (2006) Efeito de reguladores vegetais na germinação e desenvolvimento da semente Strelitzia reginae. Thesis. 5:161-176.

García-Flórez M, Portela-Ramírez A, Flórez-Roncancio VJ (2009) Sustancias con actividad citoquinínica estimulan La brotación de yemas en tuberculos de papa. Bragantia. 68:555562.

Oliveira AP, Júnior RJF, Bruno RLA (2001) Efeito de baixa temperatura e do carbureto de cálcio na emergência de túberassemente do inhame. Hortic Bras. 19:250-252.

Ono EO, Júnior JFG, Rodrigues JD (2004) Reguladores vegetais na quebra da dormência apical de mamoeiro (Carica papaya L.). Rev Bras Frutic. 26:348-350.

Rubatzky VE, Yamaguchi M (1997) World vegetables: Principles, production, and nutritive values. $2^{\mathrm{a}}$ ed. Chapman $\&$ Hall: Nova York. 843p.

SAEG - Sistema para Análises Estatísticas, 2007. Versão 9.1: Fundação Arthur Bernardes - UFV - Viçosa.

Seganfredo R, Finger FL, Barros RS, Mosquim PR (2001) Influência do momento de colheita sobre a deterioração póscolheita em folhas de taioba. Hortic Bras. 19:316-319.

Souza CS, Finger FL, Casali VWD, Cecon PR (2014) Effect of cold storage on enzyme activity and postharvest conservation of tannia (Xanthosoma sagittifolium) leaves. Aust J Crop Sci. 8:1380-1387.

Souza, CS, Finger FL (2014) Reguladores vegetais sobre a brotação e crescimento de taioba refrigerada [Xanthosoma sagittifolium (L.) Schott]. Rev Raízes Amidos Trop. 10:87-96.

Suttle JC (1998) Involvement of ethylene in potato microtuber dormancy. Plant Physiol. 118:843-848.

Suttle JC (2009) Ethylene is not involved in hormone- and bromoethane-induced dormancy break in russet burbank minitubers. Am J Potato Res. 86:278-285.

Taiz L, Zeiger E (2002) Plant physiology. 3.ed. Sunderland: Sinauer Associates. p.423-460.

Vieira AR, Oliveira JA, Guimarães RM, Pinho EVRV, Pereira CE, Clemente ACS (2008) Marcador isoenzimático de dormência em sementes de arroz. Rev Bras Sementes 30:8189.

Vieira RF, Silva CM, Souto ER, Hata FT, Machado MFPS, Marcuz FS (2009) Diferentes concentrações de 6benzilaminopurina e cinetina na micropropagação in vitro das variedades RB867515 e RB855156 de cana-de-açúcar. Campo Digital. 4:122-126. 